\title{
Designing a Learning Management System based on Cyber Pedagogy for Higher Education
}

\author{
Paula Dewanti \\ Institute of Technology and \\ Business STIKOM Bali
}

\author{
I. Made Candiasa \\ Ganesha University of Education
}

\author{
I. Made Tegeh \\ Ganesha University of Education
}

\begin{abstract}
This study aims to design a Learning Management System (LMS) model that will provide a learning ecosystem that is suitable for the characteristics of students in higher education, in order to achieve an effective and efficient learning process in ways that are simple, interesting, and interactive by utilizing various multidimensional learning resources in Cyber Pedagogy. The research was carried out both quantitatively and qualitatively. This study's population is a student at the Institute of Technology and Business (ITB) STIKOM Bali, Faculty of Information Systems (IS), with 53 respondents, including three lecturers in the stage of expert testing, who are Learning Media Expert, Instructional Design Expert, and Teaching Expert, and 50 student respondents. The LMS Model that will be created is known as a SMILE, which stands for a Simple, Multidimensional, and Interactive Learning Ecosystem. This SMILE Model is expected to address the needs and challenges of learning in the 21st century, particularly for the millennial generation, which represents the largest market share of the current college, and for whom the use of information technology is one of their notable characteristics. During the implementation stage, a Blended Learning approach will be used in a different format during the pandemic, with a live face-to-face session in a virtual classroom used as a substitute for conventional face-toface interaction in a classroom.
\end{abstract}

\section{General Terms}

Cyber Pedagogy, E-Learning, Learning Model, Learning Management System.

\section{Keywords}

Cyber pedagogy, e-learning, learning model, learning management system.

\section{INTRODUCTION}

Education broadens and encourages our minds to look deeper into the possibilities that exist, fostering the ability to think creatively. The presence of information technology in it plays a significant role in assisting students in completing the learning process to the best of their potential [6]. Since the 20th century, the approach used in the educational system has evolved from the improvement through repetition method to a new approach that emphasizes the learning process independently. The Distance Learning through E-Learning system was designed with flexibility and individualization in mind to address the challenges of lifelong learning and to ensure student productivity [18].

In this study, a web-based application design Learning Management System (LMS) model called Simple, Multidimensional, and Interactive Learning Ecosystem (SMILE) will be developed, which will be accessible via various browsers on mobile devices and Personal Computers (PCs). The developed LMS is expected to help students understand learning in a more enjoyable and engaging manner, as well as to provide a different atmosphere and approach to the millennial generation's learning process, allowing them to maximize their potential and increase competence.

The SMILE model was created with the help of researchers for students, specifically for the E-Tourism course, using the Blended Learning approach, which combines E-Learning and virtual learning, which is the new face-to-face norm during the Covid-19 pandemic. The SMILE model is based on constructivism learning theory and Cyber Pedagogy.

The constructivism theory principles and procedures used to strengthen the SMILE model are how students build their own knowledge, where knowledge preparation is obtained from concrete experience, through collaborative activities, reflection and interpretation with an activity that allows students to have different understandings of knowledge, and perspective used in interpreting it. While the principles of Cyber Pedagogy applied to the SMILE model include each student having free and independent access to various learning resources from anywhere, at any time, and in various ways, learning occurs in multi-directional egalitarian, inclusive, and non-bureaucratic ways through interaction and feedback that can occur at any time when desired - formally or informally, and students are in full control of their learning and learning process. Administrators, Lecturers, and Students are the SMILE application's actors (users), with varying levels of access. The actors will be assigned a user name and password that will allow them to access the SMILE application and its existing features online.

Research Wang et al. (2012) use Facebook Groups as part of their LMS development because they have potential pedagogical, social, and technological capabilities that allow for the sharing of ideas, resources, announcements, and online discussions. Aside from the limitations of directly uploading files of various formats, the discussion is not organized in a meaningful structure. Facebook usage has two sides. Learners communicate and interact with their peers and other learners with ease. However, due to a lack of privacy, there is a failure to provide a safe social environment [19].

Shin and Kang (2015) use a mobile application-based LMS to assess student acceptance and its impact on learning objectives achievement. According to research, students at online universities are beginning to accept mobile technology as a new learning tool. This acceptance has an impact on student learning achievement, either directly or indirectly. These findings help to improve understanding of the use of mobile learning systems in higher education and provide appropriate guidance for the development and implementation of mobile application-based LMS [17].

A previous study on the use of LMS in universities was conducted in Africa. According to Mtebe (2015), the use of LMS in universities in Sub-Saharan Africa is increasing and consuming a substantial portion of their limited resources to 
install and maintain their LMS. Mtebe examines published literature on the use of LMS in Sub-Saharan Africa and proposes strategies to help institutions make better use of their LMS. It aims to assist institutions in identifying effective strategies to encourage increased use of their LMS while saving money [12].

\section{THEORETICAL STUDY}

\subsection{LMS Development in Higher Education}

According to Lopes (2014)'s research, there are numerous advantages to using a learning management system (LMS) such as Moodle to support high-level lectures. By considering the implications as advocates for the participant students and online interaction, the lead agency of education to collaborate on environmental learning that is different, in which they can combine instruction face-to-face with instruction mediated by the computer, and improves person's communication ability, both in terms of quality and quantity, in the background of learning [10]. LMS components, in general, include synchronous and asynchronous communication tools, management features, and assessment utilities. This grading tool enables Lecturers to automate basic grading tasks. Ratings can be delivered directly to participants and returned with the value and feedback detailed [9]. Synchronization enables participants to discuss with the instructor as well as with one another via the Internet at the same time, using tools such as video conferencing and room chat. This has the advantage of providing instant feedback. However, the Asynchronous mode also allows participants to communicate with the instructor or teacher as well as between themselves via the Internet at a different time. Because it is not the same interaction at the same time, but then, using tools such as Forum Discussion and email, with the advantage that the participant students can learn at a time that is convenient for them, while the disadvantage is that the participant students will not be able to receive feedback through instant of instructors and participants students [5]. The theory/concept of learning has also changed the role of teachers and learners. It evolved into a system that considers the learner's autonomy. From a didactic perspective, LMS is the best way for teachers to organize, manage, and deliver subject matter through the use of multimedia tools to create engaging activities that make the learning process more learner-friendly [1].

LMS in Higher Education has been widely developed, and each institution's needs are catered to. LMS development is accomplished through the use of open source applications such as Moodle, Sakai, and others, as well as the development of pages Web by institutions themselves. Among them are the following:

(1) Coursera is an online learning platform founded in 2012 by Andrew Ng, a Stanford professor of computer science, and Daphne Koller. Coursera provides open online courses (MOOCs), program specialization, and program titles in a variety of subjects, including Engineering, Mathematics, Business, Science Computer, Marketing, Humanities, Medicine, Biology, Social Sciences, and others, in collaboration with universities and organizations.

(2) edX is also one of the providers of the University of Harvard and MIT's courses online open (MOOC) site. edX, like Coursera, is a provider of Higher Education (universities) online courses in various disciplines of science for participants from all over the world, including some free courses. edX is a non-profit organization that operates on the Open edX free opensource software platform.

(3) Indonesia developed SPADA Indonesia (Indonesian Online Learning System), one of the programs of the Ministry of Research, Technology, and Higher Education's Directorate-General Education and Student Affairs, to improve equitable access to learning. SPADA Indonesia's online learning system allows students to follow a specific course at another university, and the results of that learning can be recognized equally by the university where the students are enrolled.

(4) SEAMOLEC Open Learning Center is one of the education centers in Southeast Asia under the auspices of the Southeast Asian Ministers of Education Organization (SEAMEO) that is engaged in the field of research and development, training, technology, and information, sharing expertise and sources of power on the inside and outside of the Asian region southeast in the field of open and distance education. SEAMOLEC's Training feature includes Online Training and Face-to-Face Training, both of which offer a variety of course fields in the field of Information and Communication Technology (ICT).

Using data from the Survey of National Involvement of Students, Dumford and Miller (2018) investigate how the course through media online affects the involvement of participants learners. The study's findings revealed that there is a significant relationship between taking online courses and student involvement for students in their first and senior years. Students who take many courses online are more likely to be involved in quantitative reasoning. They do, however, engage in collaborative learning, interaction between student and faculty, and a variety of discussions with other people, whereas their counterparts' classes are more traditional. The relationship between these indicators of involvement and the percentage of classes taken online simply shows that the online environment may be advantageous for some, but it may also be a deterrent for others. Institutions should consider these findings when designing online courses, and faculty should think more about how to encourage participant students' involvement in various types of learning delivery [4].

Flavin (2017) discusses the difficulties in implementing digital learning. In line with the development of digital learning, there are many opportunities brought by new students as technology innovators, but the university may not accept the new technology that they brought. Furthermore, students and lecturers may be unwilling to use technology to support their learning and teaching [7].

\subsection{Cyber Pedagogy}

The effects of learning in the digital age have changed the structure of the system of Open and Distance Learning (ODL), of the materials studied printing traditionally become the source of power of education online; counseling and guidance into online interaction, and online student support services via email, WhatsApp, SMS, and others [3]. The introduction of application-based mobile on smart phones, as well as the proliferation of Internet mobile in the $21^{\text {st }}$ century, has altered the patterns of thought of practitioners, educators, and administrators all over the world. It implements new teaching methods that are in accordance with the needs of the participating students, as a result of an increase in demand for 
innovative teaching and learning methods [15].

Nixon (1999) stated that learning to use computer media is considered the antithesis of learning that is considered "boring" associated with "old" chalk and verbal technology, or pen and paper. Overall, the argument is made that new forms of literacy and cyber pedagogy are needed globally in the future; provide added value, inspire and build engagement; and can be accessed via multimedia and the Internet [11].

UNESCO launched the UNESCO Strategic Framework for Education, a global initiative to reimagine how knowledge and learning can shape the future by catalyzing a global debate on how knowledge, education, and learning must be reorganized in an increasingly complex, uncertain, and foreshadowing world. Cyber Pedagogy is the science or art of teaching in an online environment. Pedagogy Cyber focuses on the reasons and teaching methods that are best suited to the specific technology used, as opposed to the inverse of what is perhaps better suited to the traditional face-to-face classroom context [8]. Indrajit (2017) describes the Principles of Cyber Pedagogy as follows:

(1) Each participant learners can access a variety of resources to learn as freely and independently in the $24 / 7$.

(2) Method process towards the source of learning are ubiquitous, many of which alone, when alone, and in various ways.

(3) The Internet's source is dynamic, and it is updated every second of the day.

(4) The learning process tends to be intuitive, contextual, and critical.

(5) Learning takes many forms in an egalitarian, inclusive, and non-bureaucratic environment.

(6) Interaction and feedback can occur when only desirable - whether formal or informal.

(7) Evaluating the learning process can be done at any time and in a variety of ways.

(8) Participants and students have complete control over the learning and teaching process.

Furthermore, Indrajit explained that the institution must have a student center (Student Centered Learning) where knowledge transfer can be centered on the student as one form of Cyber Pedagogy. Student Centered Learning (SCL) is based on constructivism as a learning theory that is based on the idea that students should construct and reconstruct knowledge to be effective. Learning is most effective when it is integrated into an activity, and student experience creates products that significantly improve learning [8]. Learners mentor, direct, guide, and monitor participant students as they use all available sources of learning on the Internet, ensuring that the source of learning is used appropriately and optimally.

\section{RESEARCH METHOD}

Figure 1 depicts the Waterfall Method as the research method used in this study. The waterfall model describes a sequential software flow approach that begins with requirement (need analysis) and progresses through design, implementation (coding, testing), and maintenance (support) stages. Each phase was preceded by and completed one at a time [11].

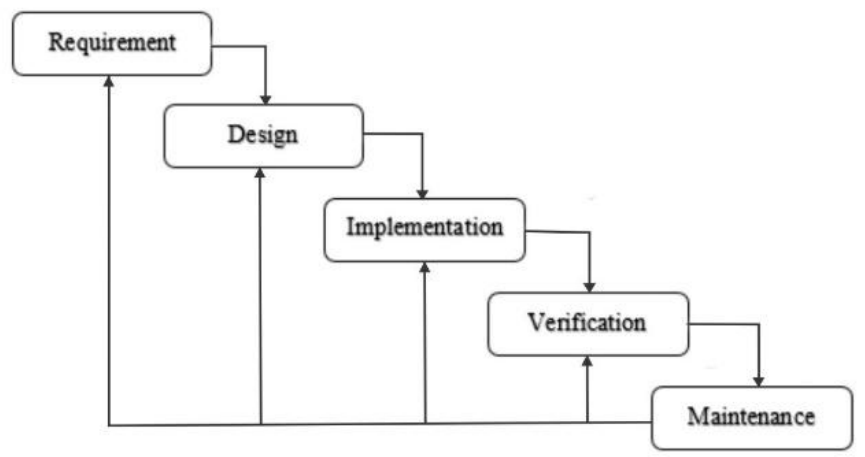

Fig 1: Waterfall Methods

\subsection{Requirements}

The first stage, Requirements Analysis, involves conducting a needs analysis in the development of the SMILE, which includes both functional and non-functional requirements.

\subsection{Design}

The System Design stage is where the previous stage's requirements specifications are studied and the system design is prepared. System design assists in determining hardware and defining overall system architecture. Flowcharts, Entity Relationship Diagrams (ERD), and Conceptual Databases were used to define the overall system architecture.

\subsection{Implementation}

At the System Implementation stage, programming or coding is performed, which is the translation of the design into a computer-readable language. In addition to programming, there will be an inspection stage of the generated program units.

\subsection{Verification}

The system testing method used at this stage is Black Box Testing. Testing is performed to ensure quality and to identify flaws in the system to be produced, with the main goal of ensuring that the input and output results are carried out in accordance with the previously planned system functionality. In addition, a survey was applied to determine whether the system developed met the research objectives.

\subsection{Maintenance}

The System Maintenance Phase includes all processes required to ensure the system's continuity, smoothness, and refinement. The system or program is ready for use after the stages of analysis, design, and implementation, as well as testing the completed system. The final stage is maintenance, before the system is given to user subjects for use.

\section{RESULTS AND DISCUSSION}

\subsection{Entity Relationship Diagram (ERD)}

ERD displays data models that exist in a system with entities and relations [16]. The Data Store from DFD is used to define entities in the organization. And each entity has an attribute that is the entity's characteristic. In the meantime, the relation serves as a link between the entities.

When similar data is grouped together to form relationships, the relationships can be classified into three types.

$$
\begin{aligned}
& \text { One-to-One Relationship } \\
& \text { One-to-Many Relationship } \\
& \text { Many-to-Many Relationship }
\end{aligned}
$$

SMILE LMS has three entities: Admin, Lecturer, and Student. 
Admin represents the system's owner. The access includes updating the user's data and deleting/inputting/updating such as create lecturer, create student, managing the class management, quiz management, class schedule management, attendance management, module management, score management, profile management, and web configuration.

Lectures in this app, the Lectures who agreed to participate in this study. Their access includes creating class, upload material, adding video link material, managing group chat, making quiz and doing an assessment, and update their profile.

The Student, is the third Actor in SMILE apps. Student is the main goals of this SMILE apps. They have access to login to the app, doing their quiz, do group chat, to view and download learning materials, to view and download their score, upload their project/assignment, as well to update their own profile.

Figure 2 illustrates the form of the ERD design in this system.

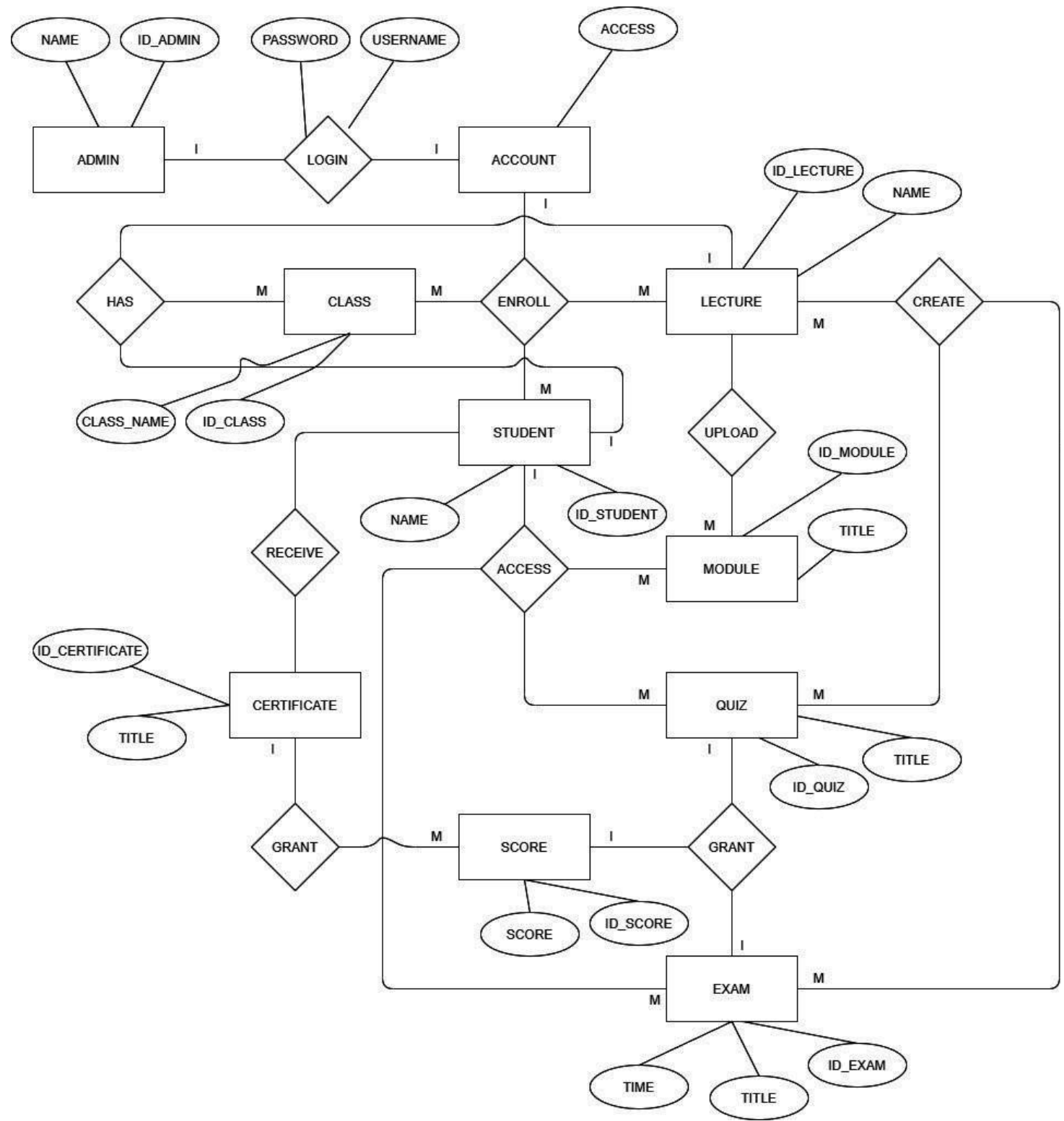

Fig 2: ERD Design 


\subsection{User Interface}

three different external entities: Admin, Lecturer, and Student.

Figures 3-8 show some of the LMS SMILE interfaces from

Log In to S M \& L E
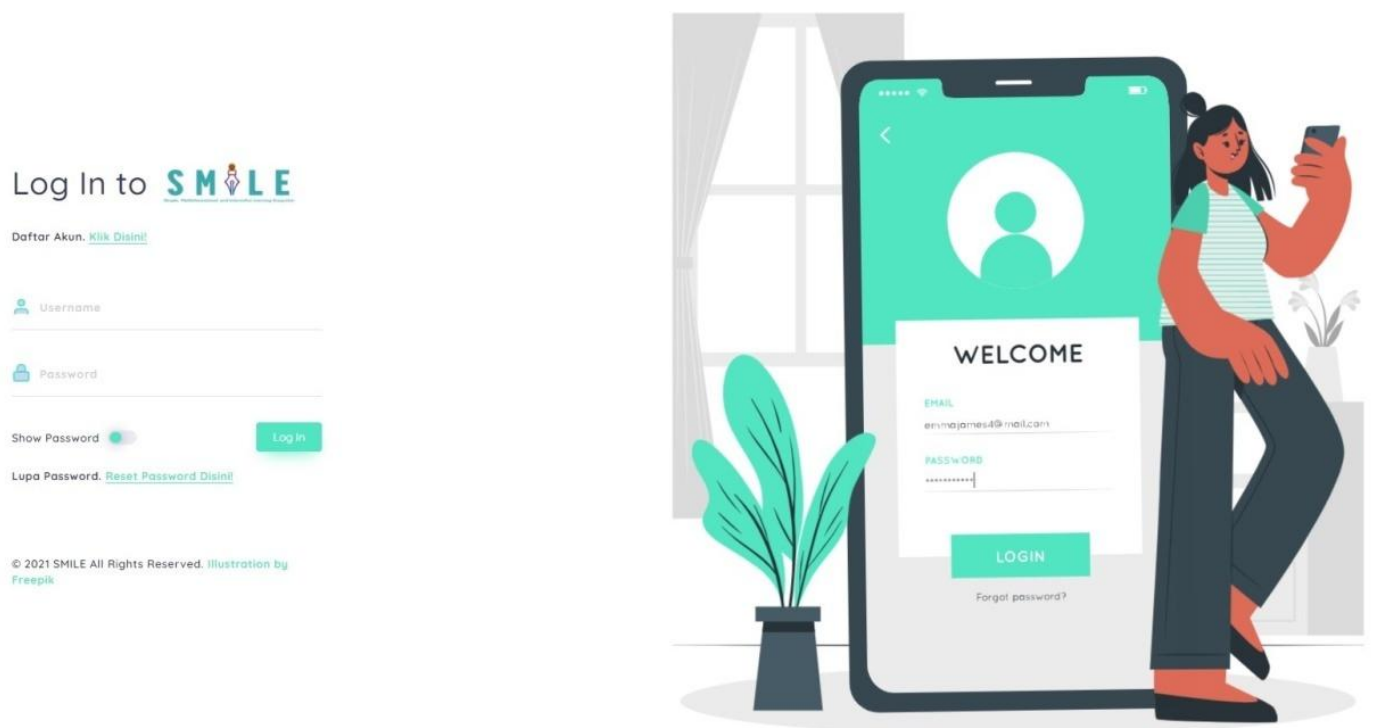

Fig 3: Login Page

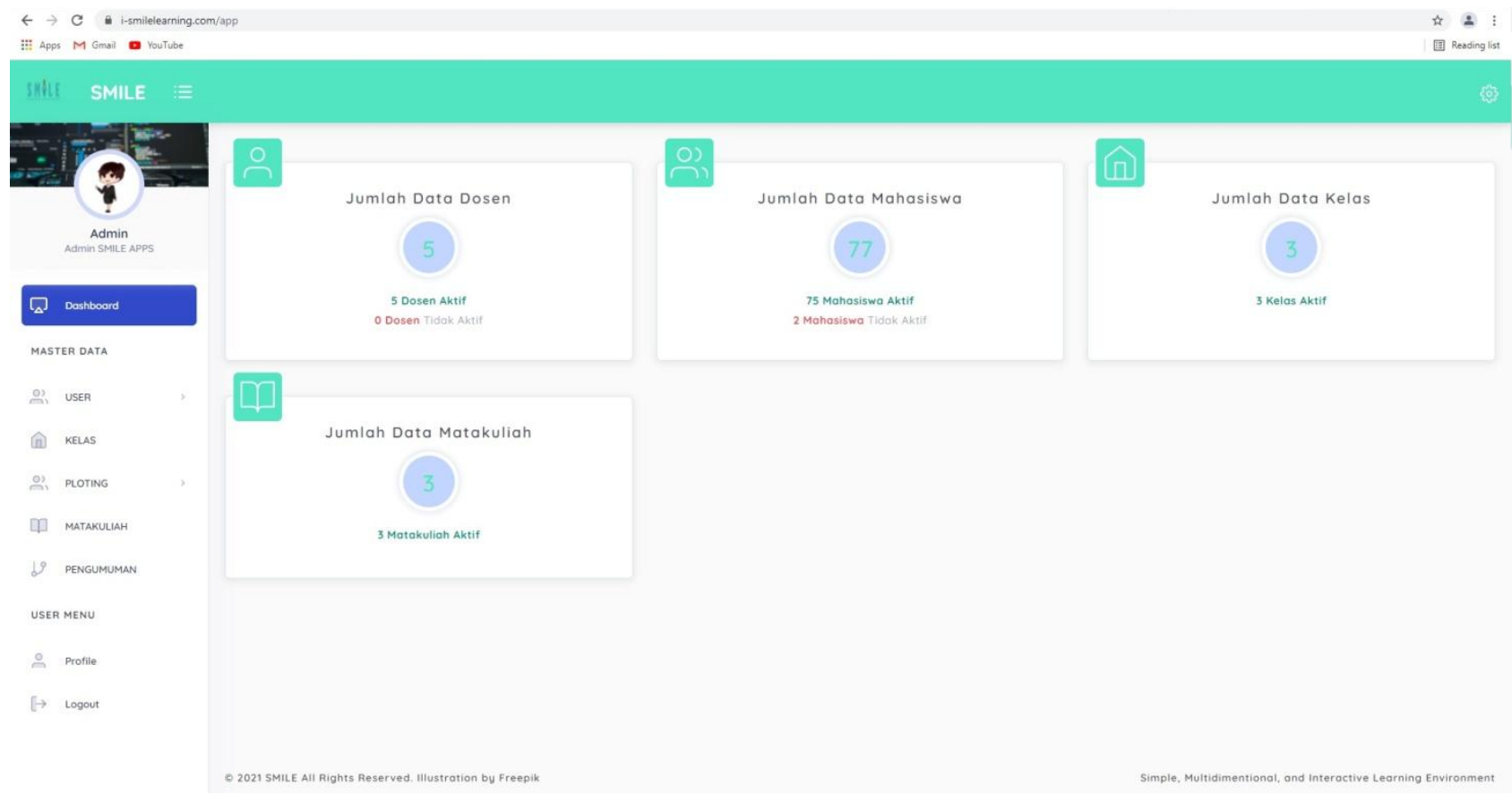

Fig 4: Admin Dashboard 
International Journal of Computer Applications (0975 - 8887)

Volume 183 - No. 27, September 2021

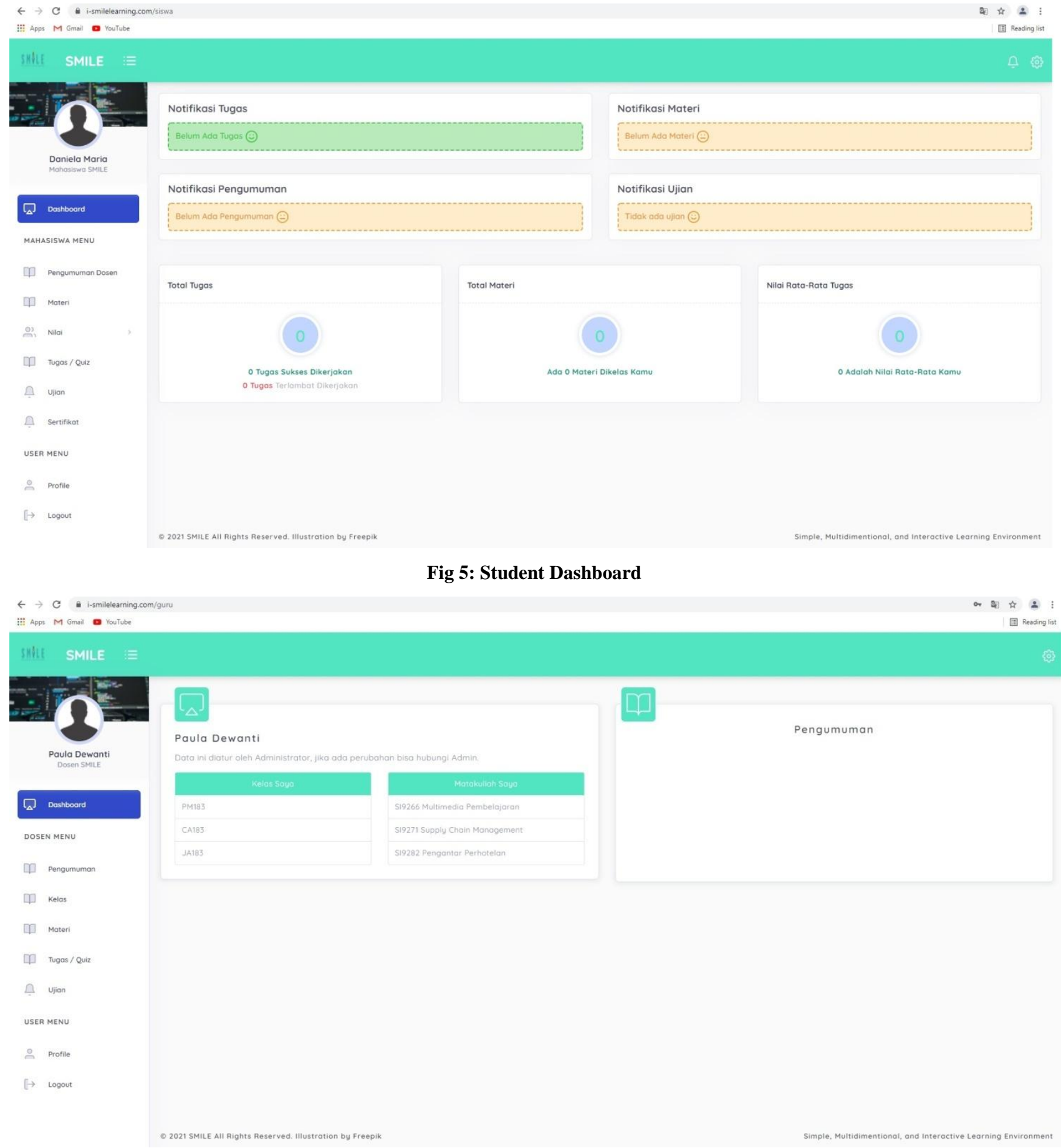

Fig 6: Lecturer Dashboard 


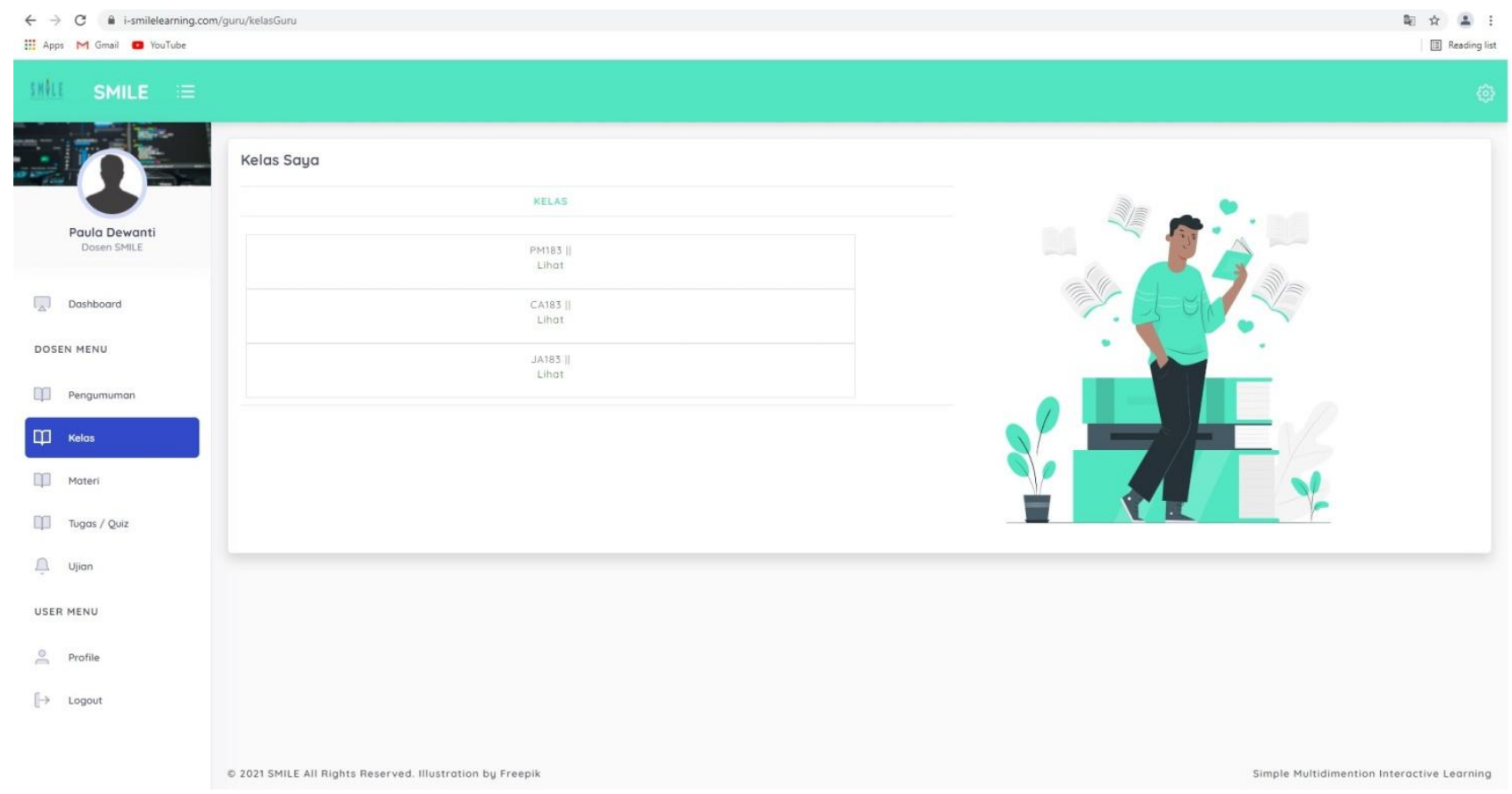

Fig 7: Lecturer Menu - Class

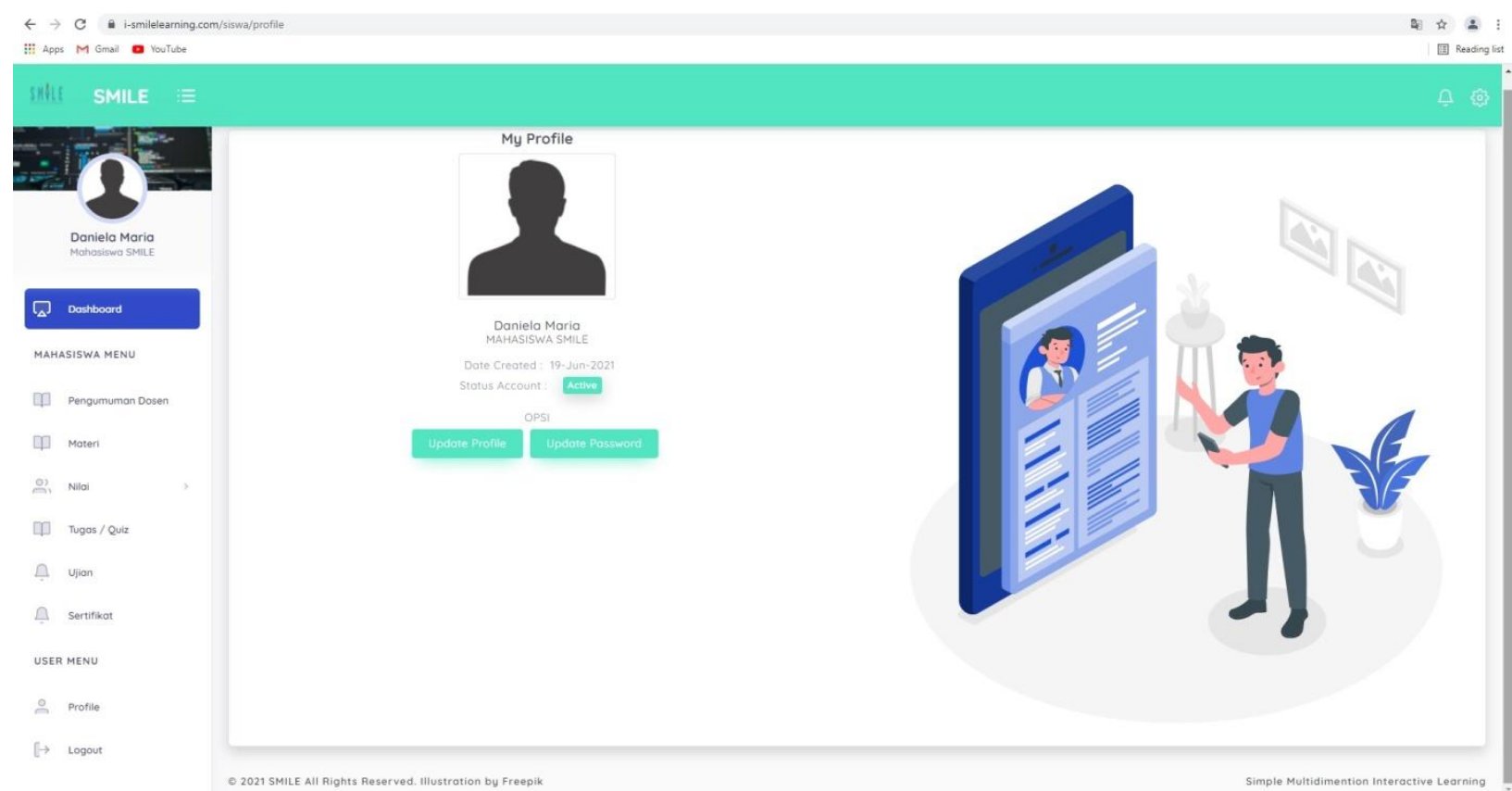

Fig 8: Profile Menu

\subsection{Black Box Testing}

The Black Box Testing method is an application test based on the user's point of view, making it easier to identify existing problems that can be fixed later.
The results of the SMILE model test using the Black Box Testing method are very good, with users being able to access all of the system's menus properly and in accordance with the expected results. Figures 9-12 are three samples of Black Box Testing results taken form SMILE testing. 


\begin{tabular}{|c|c|c|c|c|}
\hline No & Data Input & Expected Results & $\begin{array}{l}\text { Observation } \\
\text { Result }\end{array}$ & Conclusion \\
\hline 1 & $\begin{array}{l}\text { The lecturer clicks } \\
\text { the "Assignments / } \\
\text { Quiz" button on the } \\
\text { left sidebar. }\end{array}$ & $\begin{array}{l}\text { The "Add } \\
\text { Assignments/Quiz" } \\
\text { page will be } \\
\text { displayed by the } \\
\text { system. }\end{array}$ & $\begin{array}{l}\text { The system } \\
\text { successfully } \\
\text { displays the } \\
\text { "Add } \\
\text { Task/Quiz" } \\
\text { page. }\end{array}$ & Succeed \\
\hline 2 & $\begin{array}{l}\text { The lecturer clicks } \\
\text { the "Assignments / } \\
\text { Quiz" button on the } \\
\text { left sidebar; then } \\
\text { clicks the "Add } \\
\text { Assignments / } \\
\text { Quiz" button. }\end{array}$ & $\begin{array}{l}\text { The system will } \\
\text { display the "Add } \\
\text { Assignments/Quiz" } \\
\text { detail page. } \\
\text { The lecturer adds } \\
\text { assignments/quiz } \\
\text { and clicks the } \\
\text { "Save" button. }\end{array}$ & $\begin{array}{l}\text { The system has } \\
\text { successfully } \\
\text { displayed the } \\
\text { Add } \\
\text { Assignment } \\
\text { /Quiz detail } \\
\text { page, which } \\
\text { contains } \\
\text { information on } \\
\text { how to add } \\
\text { Assignments/ } \\
\text { Quiz for } \\
\text { Students. } \\
\text { The Lecturer } \\
\text { has added the } \\
\text { Assignment } \\
\text { /Quiz } \\
\text { successfully, } \\
\text { and the system } \\
\text { will revert } \\
\text { back to the } \\
\text { Assignment } \\
\text { /Quiz page. }\end{array}$ & Succeed \\
\hline
\end{tabular}

Fig 9: Lecturer Menu - Assignment and Quiz 


\begin{tabular}{|c|c|c|c|c|}
\hline No & Data Input & Expected Results & $\begin{array}{l}\text { Observation } \\
\text { Result }\end{array}$ & Conclusion \\
\hline 1 & $\begin{array}{l}\text { Students click the } \\
\text { "Material" button } \\
\text { in the left sidebar. }\end{array}$ & $\begin{array}{l}\text { The Materials page } \\
\text { will be displayed } \\
\text { by the system. }\end{array}$ & $\begin{array}{l}\text { The Materials } \\
\text { page is } \\
\text { successfully } \\
\text { displayed by } \\
\text { the system. }\end{array}$ & Succeed \\
\hline 2 & $\begin{array}{l}\text { The student clicks } \\
\text { the "View" button. }\end{array}$ & $\begin{array}{l}\text { The Material detail } \\
\text { page will be } \\
\text { displayed by the } \\
\text { system. }\end{array}$ & $\begin{array}{l}\text { The system } \\
\text { successfully } \\
\text { displays the } \\
\text { Material detail } \\
\text { page. }\end{array}$ & Succeed \\
\hline
\end{tabular}

Fig 10: Student Menu - Subject Matter Material

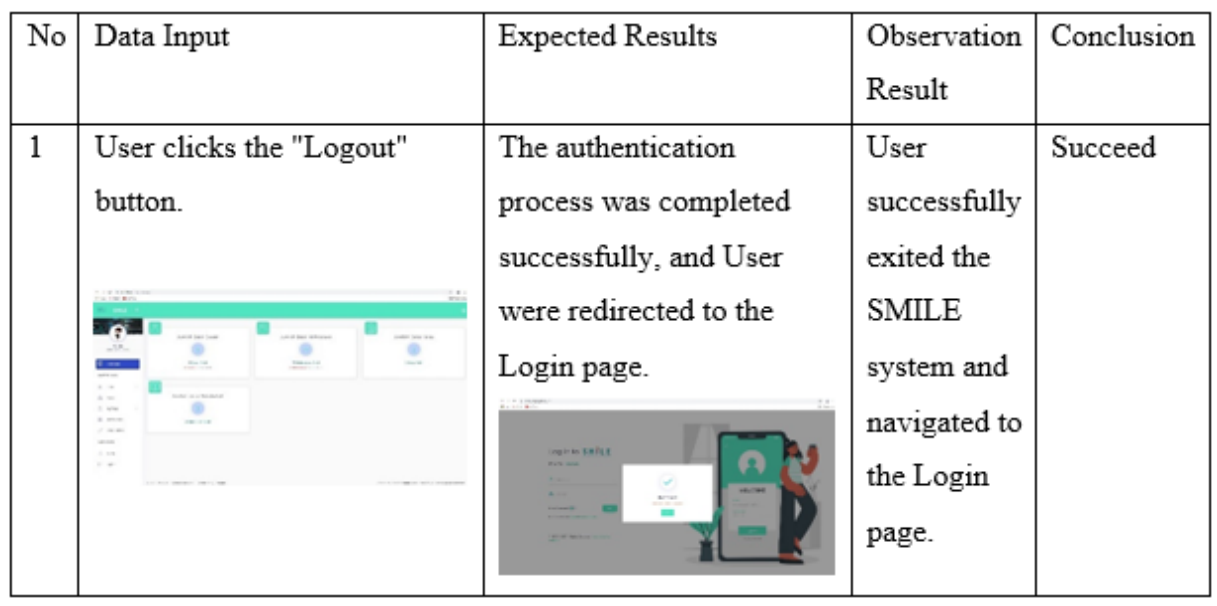

Fig 10: Logout Page 


\begin{tabular}{|c|c|c|c|c|}
\hline No & Data Input & Expected Results & $\begin{array}{l}\text { Observation } \\
\text { Result }\end{array}$ & Conclusion \\
\hline 1 & $\begin{array}{l}\text { Admin correctly enters } \\
\text { the Username (email } \\
\text { address) and Password } \\
\text { and clicks the "Log In" } \\
\text { button. }\end{array}$ & $\begin{array}{l}\text { The authentication process } \\
\text { was successful and user was } \\
\text { redirected to the } \\
\text { "Dashboard" page (main } \\
\text { page). }\end{array}$ & $\begin{array}{l}\text { Admin has } \\
\text { successfully } \\
\text { navigated to } \\
\text { the } \\
\text { "Dashboard" } \\
\text { page (main } \\
\text { page). }\end{array}$ & Succeed \\
\hline 2 & $\begin{array}{l}\text { Admin enters an } \\
\text { incorrectly formatted } \\
\text { Username (email } \\
\text { address) and Password } \\
\text { and clicks the "Log In" } \\
\text { button. }\end{array}$ & $\begin{array}{l}\text { The system will display a } \\
\text { prompt comment box to enter } \\
\text { the Username (email address) } \\
\text { with the correct format. }\end{array}$ & $\begin{array}{l}\text { The Admin } \\
\text { was unable to } \\
\text { login and was } \\
\text { redirected to } \\
\text { the login page. }\end{array}$ & Succeed \\
\hline 3 & $\begin{array}{l}\text { Admin does not enter a } \\
\text { Username (email } \\
\text { address) or Password } \\
\text { before clicking the } \\
\text { "Log In" button. }\end{array}$ & $\begin{array}{l}\text { The system will display a } \\
\text { comment box with the words } \\
\text { "Please fill out this field" to } \\
\text { allow you to fill in the } \\
\text { blanks. }\end{array}$ & $\begin{array}{l}\text { The system } \\
\text { redirects to the } \\
\text { login page } \\
\text { successfully. }\end{array}$ & Succeed \\
\hline 4 & $\begin{array}{l}\text { Admin types in the } \\
\text { incorrect Username } \\
\text { (email address) and } \\
\text { Password and clicks } \\
\text { the "Log In" button. }\end{array}$ & $\begin{array}{l}\text { The system will notify you if } \\
\text { the Username (email address) } \\
\text { or Password you entered is } \\
\text { incorrect. }\end{array}$ & $\begin{array}{l}\text { The system } \\
\text { displays a } \\
\text { successful } \\
\text { notification } \\
\text { that the } \\
\text { Username } \\
\text { (email } \\
\text { address) or } \\
\text { Password }\end{array}$ & Succeed \\
\hline
\end{tabular}

Fig 12: Admin Menu - Login Page Testing

\section{CONCLUSION}

The development of this SMILE Learning Management System model is expected to assist students understand learning, become more interested in understanding, as well as provide a different environment and approach to help students maximize their potential and competencies.

This research will be used to advance the ADDIE instructional model's final two phases: implementation and evaluation, which are designed to assess the effectiveness and efficiency of the learning process using the developed learning module.

\section{ACKNOWLEDGMENTS}

Thank you to all of the experts who contributed to the development of the research, including the corresponding author advisors, Dr. I Gde Wawan Sudatha, and Profesor Naswan Suharsono, as well as all students, the Learning Media Expert, Instructional Design Expert, and a Teaching Expert.

\section{REFERENCES}

[1] Arkorful, V., \& Abaidoo, N. 2015. The role of e- 
learning, advantages and disadvantages of its adoption in higher education. International Journal of Instructional Technology and Distance Learning, 12(1), 29-42.

[2] Cavus, N., \& Alhih, M. S. 2014. Learning management systems use in science education. Procedia-Social and Behavioral Sciences, 143, 517-520.

[3] Dewanti, P. 2016. Linking national standards of distance education with e-learning ecosystem. Journal of Theoretical \& Applied Information Technology, 86(3).

[4] Dumford, A. D., \& Miller, A. L. 2018. Online learning in higher education: exploring advantages and disadvantages for engagement. Journal of Computing in Higher Education, 30(3), 452-465.

[5] Elyas, A. H. 2018. Penggunaan Model Pembelajaran ELearning Dalam Meningkatkan Kualitas Pembelajaran. Warta Dharmawangsa, (56).

[6] Faiella, F., \& Ricciardi, M. 2015. Gamification and learning: a review of issues and research. Journal of eLearning and Knowledge Society, 11(3).

[7] Flavin, M. 2017. Disruptive technology enhanced learning: The use and misuse of digital technologies in higher education. Springer.

[8] Indrajit, R. E. 2017. Ecosystem Framework for Ubiquitouse Learning Implementation.

[9] Jan, S. R., Shah, S. T. U., Johar, Z. U., Shah, Y., \& Khan, F. 2016. An innovative approach to investigate various software testing techniques and strategies. International Journal of Scientific Research in Science, Engineering and Technology (IJSRSET), Print ISSN, 2395-1990.

[10] Lopes, A. P. 2014. Learning management systems in higher education. In EDULEARN14 Conference (pp. 5360-5365). Proceedings of EDULEARN14 ConferenceIATED Publications.

[11] Mahalakshmi, M., \& Sundararajan, M. 2013. Traditional
SDLC vs scrum methodology-a comparative study. International Journal of Emerging Technology and Advanced Engineering, 3(6), 192-196.

[12] Mtebe, J. 2015. Learning management system success: Increasing learning management system usage in higher education in sub-Saharan Africa. International Journal of Education and Development using ICT, 11(2)

[13] Nemoto, T., \& Beglar, D. 2014. Likert-scale questionnaires. In JALT 2013 conference proceedings (pp. 1-8).

[14] Nixon, H. (1999). Towards a (Cyber) pedagogy for multimedia multiliteracies. Teaching Education, 10(2), $87-102$

[15] Novojen, O., \& Birnaz, N. 2019. Ecosystem of Learning in Initial Vocational Education and Training: An Innovative Model for Development of Entrepreneurial Competence. In Handbook of Research on EcosystemBased Theoretical Models of Learning and Communication (pp. 194-210). IGI Global.

[16] Permana, P. A. G., \& Dewanti, P. 2019. Designing Temporary Resident Information Systems: Case Study of a Village in Bali. In 2019 1st International Conference on Cybernetics and Intelligent System (ICORIS) (Vol. 1, pp. 195-199). IEEE.

[17] Shin, W. S., \& Kang, M. 2015. The use of a mobile learning management system at an online university and its effect on learning satisfaction and achievement. International Review of Research in Open and Distributed Learning, 16(3), 110-130.

[18] Tanenbaum, A. S. 2016. Structured computer organization. Pearson Education India.

[19] Wang, Q., Woo, H. L., Quek, C. L., Yang, Y., \& Liu, M. 2012. Using the Facebook group as a learning management system: An exploratory study. British journal of educational technology, 43(3), 428-438. 